\title{
C.R. PARSONS
}

\section{INTRODUCTION}

In any organisational structure, either in private or public sectors, the lines and methods of communication need to be fully understood and utilised by everyone in the organisation if efficiency of the institution or service is to be obtained. Communication may be upward, downward or horisontal, and it is essential for cohesion and morale in the institution that there is accuracy and courtesy throughout each stage of communication. Breakdown in communication at any point in the process or at any level in the hierachy will affect the functioning and the reputation of the whole institution or service.

For sound professional relationships among personnel and for effective achievement of institutional objectives co-operation between staff members (team members) is essential. The correct choice of suitable ways for establishing co-operation is important, and it should be remembered that co-operation, like communication, is a two-way process. For clarity and accuracy, to avoid any misunderstanding and, even more important, to maintain accountability it is better in the public sector that information be conveyed in writing - even if preceded by informal verbal communication. Two methods of conveying information and helping to establish co-operation in any organisation are the use of reports and memoranda.

The discussion which follows examines briefly the types, writing, and

\footnotetext{
C.R. Parsons

Department of Public Administration. University of Port Elizabeth
}

\section{OPSOMMING}

Van alle vorme van kommunikasie in organisasies is verslae en memoranda die twee wat die meeste gebruik word omdat hulle aanpashaar - hulle voorsien aan meeste van die organisasic se behoeftes - en geskrewe is, wat latere misverstande en waninterpretasie van gebeure voorkom. Hulle is permanente rekords.

Memoranda kan vir opwaartse, afwaartse of horisontale kommunikasie gebruik word om versoeke en inligting oor te dra. Verslae verteenwoordig opwaartse kommunikasie. Beide is belangrik vir inter-en binnedepartementele samewerking en koordinasie. Verslae het die bykomende voordeel dat hulle beheer, navorsings, onderrig en evaluasie maatreëls binne die organisasie kan wees.

uses of reports and memoranda. This discourse is not intended to be exhaustive, but to serve merely to make the users of reports and memoranda more conversant with the technicalities of these tools and the variety of uses to which they may be put.

\section{REPORTS}

\section{Definition}

According to the Concise Oxford Dictionary a report is an account given or opinion formally expressed after an investigation/consideration or the collating of information. In addition, Denyer sees a report as ... a means of communication in which the writer sets down some conclusion or recommendation from facts or circumstances which have been investigated (Denyer, 1973).

From this it may be inferred that a report is given once some activity or process has been completed. Such a report states ascertained facts, being a record or description of something seen, read or heard by the reporter and passed on to the reader or hearer for a purpose, as (i)nformation and recommendation... are of little value unless they assist in the formation of judgements and lead to decisions being taken (Mills, 1971). Therefore, a report which does not stimulate thought and lead to eventual action serves no useful purpose.

\section{Types of reports}

There are various types of reports which may be used in public institutions.

\section{Routine reports}

Routine reports are usually used for information or internal control purposes. These may be on a specially printed form when they are submitted at regular intervals, for example statistical returns. Every institution will have a series of routine reports which are considered necessary for the effective and efficient achievement of institutional objectives. In a hospital such reports may include, inter alia

- reports on the clinical condition of patients and on nursing processes,

- staff performance reports,

- student learning, progress reports, and

- daily bed-state returns.

\section{Informal reports}

Informal reports are usually written by individuals within an institution. They may take the form of, for example, a memorandum, or they may refer to specific/special matters. Very rarely such reports may be verbal. Commonly used reports of this nature include, inter alia

- reports on use of equipment and on supplies being tested and - interim research reports. 


\section{Formal reports}

Formal reports may take the form of, inter alia

- minutes of meetings,

- inspection reports,

- research reports,

- reports of effectiveness audit committees, and

- reports by individuals after they have attended symposia or congresses.

\section{Statutory reports}

Statutory reports are those reports which are required by law, for example, annual reports, or in a hospital, reports on incidents or accidents involving patients/personnel which may have repercussions, namely

- patient injury reports medicallegal risk), and

- staff injury reports (Workman's Compensation Act requirement).

Reports represent an upward communication and all reports are to some extent control measures as they are feedback on 'events that have happened. Reports thus

- make it possible for deviations from policy to be determined, and reasons for this deviation may be investigated, eliminated or corrected;

— indicate progress being made in learning or research situations, or in bringing about change within the institutional establishment (structure) or procedure; and

- permit standards of effectiveness/efficiency to be assessed and improved upon.

\section{Format and presentation}

The format of a report varies with its type and the custom of the institution or service. Basically most reports should comply with the following requirements.

\section{Contents}

The report must contain facts relevant to the situation or subject being discussed. Such facts should be set out in a logical and objective manner and should provide all the information necessary to achieve the purpose of the report. For example, in a hospital, nursing reports must not only be understood by professional persons in the course of their duties (patient care) but also by laymen (accounts office; court of law) and therefor complex terminology should be avoided or else the report should be accompanied by definitions of terms. No abbreviations should be used and exaggerations should be avoided.

\section{Format}

Reports should, as far as possible, comprise a format which makes it easy for the reader to use or to find a particular section quickly. They could include:

- a heading which indicates the contents, for example, Annual Report of ...;

- a table of contents which serves to facilitate reference if the report is long, and to indicate to the reader how the information has been arranged;

- an introduction in which any terms of reference given to the writer(s) of the report and the problem or circumstances being reported on are stated;

- a body in which numbered/ headed paragraphs set out the necessary information, arguments and/or recommendations, as may be required by the nature of the report;

- appendices which may be necessary to expand on a section of the report, but which contain information not considered to be directly relevant or essential to the matter being reported upon; and

- the signature (and rank or position held) of the person responsible for the report, for example, the chairman of a committee, department or section head. The report must also be dated.

\section{Presentation}

The presentation of the report should be appropriate to its purpose, for example, standard printed form, booklet form, typed and/or printed pages stapled together. The report should also be pleasing to the eye and easy to read. Language used should be appropriate, for example, the first person for an informal report but the third person for a formal report. Careful attention should be given to choice of words and to punctuation.

It is important to remember that there should be only one possible interpretation of the report - that is, the one the report means to convey.

\section{Use of reports}

Reports serve many purposes, but broadly speaking, they may be used as information disseminators, control measures, research instruments and teaching tools.

In a hospital, reports may fall into one of four categories. These are

- those concerning patient care, for example, patients' clinical reports or nursing audit reports;

- those concerning departmental or institution management, for example, statistical returns, reports on equipment and materials used, or annual reports;

- those concerning personnel, for example, performance reports and student progress reports;

- those concerning extra-ordinary events, for example, patient injury reports, loss of equipment or research reports.

A consideration of the reports concerning patient care can serve as an example of how reports may be used.

Patient care reports should contain information on:

- the emotional and physical condition of the patient,

- medication(s) and treatment(s) given, and still being given,

- problems which have arisen and been dealt with,

- any other factors which may have disturbed the course of recovery of that patient.

When put together in one file, such reports should provide a complete and legal record of the progress made and treatment received by the patient while in hospital. As such they constitute

a control instrument for, inter alia

- checking nursing care standards,

- evaluating in-service education within the department; 
a teaching instrument for teaching, inter alia the

- course, care and treatment of specific conditions,

- planning of nursing care,

- methods of recording patient care and treatment;

a research instrument for establishing, inter alia

- patient reactions to treatment(s),

- patient reactions to hospitalisation,

- effects on recovery rate of participation in care planning.

In exactly the same way all other reports can be used for these purposes. They can also be used to evaluate the individual who makes them.

A good report requires that the writer should have

- knowledge of the subject reported on,

- powers of observation and analytical ability (even though data may have been gathered by a number of persons on behalf of the writer),

- sound judgement without personal bias,

- accuracy of expression, and appreciation of language, and

- knowledge of report writing technique.

Examination of reports could therefore assist the evaluation of the writer's:

- ability to write a report,

- competence in assessment of a situation or person,

- degree of personal maturity and ability to evaluate objectively,

- capability in dealing with unusual as well as routine demands, both professionally and personally.

\section{MEMORANDA}

\section{Definition}

A memorandum may be a note to help the memory; a record of events for future use; a (legal) document recording terms of contract, agreement or establishment of company; informal letter without signature, or informal diplomatic message. It may also be viewed as an interoffice letter and the most common type of internal written communication (Huffman, 1965) in any institution.

From the views stated above it can be seen that the uses of memoranda are many - from a short note on a scrach pad of something still to do, or in a diary to remind of appointments or events; to intràdepartmental and inter-departmental messages and contracts. Memoranda therefore may be seen as passing horisontally, downwards or upwards within and between institutions and, as being

- informal, for example, a note to a colleague;

- semi-formal, for example, a note to the head of another department accompanying a report or statistical returns, or

- formal, for example, a request for information or new equipment, an agenda for a meeting. or to institute new policy.

\section{Format}

All memoranda, whether used in private (business) or public (central, regional or local) institutions, have similar formats, being designed to save time. It is usual for memoranda to comprise:

- a heading or letterhead indicating the institution and section concerned;

- a title stating to whom it is directed and from whom, the subject dealt with, and the date sent;

- a standard size of paper, either quarto $(1 / 2 \times \mathrm{A} 4)$ or foolscap (A4), depending on the nature of the contents and the institution filing system:

- paragraphs, each of which is numbered, short and concise, stating the information clearly. Language should be as simple as possible and the contents should indicate who, what, when, where, how and why in a logical order;

- attachments (annexures) as required for complex additional information or detail. The paragraph in the memorandum should merely indicate the main item/thought, and the fact that there is an attachment.

\section{Procedure}

Usually a separate memorandum is used for each subject as this facilitates filing. The department from which the memorandum originates keeps a copy, and the number of additional copies of any memorandum depends on its nature, for example

- to a colleague or a specific section only the original and one copy are necessary, but

- from a head office or central institution to regional offices or institutions a number of copies will need to be made.

This in turn will influence whether the memorandum is handwritten, typed, or printed.

Like reports, memoranda are stimuli to action and always necessitate some form of reaction, for example, an immediate reply (either verbally or in writing); a notation of contents for later use or incorporation in a report; or an investigation and report. While waiting for the matter to be completed the departments involved usually have a pending file in which any memorandum still being dealt with is placed in date order - either the date of receipt or of necessary completion. If a reply is merely verbal, then a note is attached to the memorandum stating the date on which the reply as received, summary of the contents of the reply and names of those involved.

Once the matter covered in the memorandum has been completely dealt with, the memorandum, together with all reply documents is filed in each of the various departments involved (or returned to central archives). The place of filing (within the department) will vary from, for example, filing cabinet to policy manual, depending on the nature of the memorandum.

\section{CONCLUSION}

Of all forms of communication in organisational structures, reports and memoranda are the two most commonly used, as they are flexible - meeting most institutional needs - and written, thus preventing later misunderstandings and misinterpretations of events. They form permanent records. 
Memoranda may be used in upward, downward or horisontal communications for conveying requests and information; while reports are upward communications which may often result from a memorandum. Both are essential for inter- and intradepartmental cooperation and co-ordination. Reports have, in addition, the advantages of forming control, research, teaching and evaluation tools within the institution or service.

\section{REFERENCES}

I. Denyer. J.C. (1973) Office management, London. Macdonald and Evans. 2nd Ed. p. 179.

2. Mills. G.: Standingford O. (1972) Office organization and method London. Pitman Publishing. p. 415.

3. Huffman. H.: Mulkemc. D. J.D.: Russon A (1965) Oifice procedures and administration New York. McGraw-Hill. p. 162.

\section{BIBLIOGRAPHY}

Concise oxford dictionary (1976) Oxford. The Clarendon Press.

DENYER. J.C.: (1973) Office administration. London. Macdonald and Evans

DENYER. J.C. (1974) Office management London. Mac donald and Evans. Ath Ed.

GOWERS. Sir Ernest (1977) Plain words (London. H.M.S.O.

HUFFMAN. H.: MULKERNE. D.J.D : and RUSSON, A (1965) Office procedures and administration New York. McGraw-Hill.

KRON, T. (1972) Communication in nursing. Philadelphia. W.B. Saunders 2nd Ed

MILIS. G.: STANDINGFORD O (1972) Office organization and method London. Pittman

TEMPLE, M. (1982) A pocker guide to writren English London. John Murray. 